Tarih Kültür ve Sanat Araştırmaları Dergisi

Revue des Recherches en Histoire Culture et Art

مجلة البحوث التاريخية و الثقافية والفنية
Vol. 7, No. 3, September 2018

Copyright (C) Karabuk University

http://kutaksam.karabuk.edu.tr

\title{
DOI: 10.7596/taksad.v7i3.1743
}

Citation: Efremova, L., Rusetskiy, M., Molchan, A., Lechman, E., \& Avdeeva, R. (2018). Russian Cultural Policy: Goals, Threats, and Solutions in the Context of National Security. Journal of History Culture and Art Research, 7(3), 433-443. doi:http://dx.doi.org/10.7596/taksad.v7i3.1743

\section{Russian Cultural Policy: Goals, Threats, and Solutions in the Context of National Security}

\author{
Lyudmila Anatolyevna Efremova ${ }^{1}$, Mikhail Gennad'evich Rusetskiy², \\ Alexey Sergeevich Molchan ${ }^{3}$, Elena Vladimirovna Lechman ${ }^{4}$, Rosa Aleksandrovna Avdeeva ${ }^{5}$
}

\begin{abstract}
The developed countries of the mid-XX century acknowledge the importance of the effective use of intellectual resources for providing sustained social development. The implementation of the formation principles of democratic information society and Russia's desire to integrate into the world community contributed to the conscious need of transiting from the paternalistic concept of cultural policy to the partnership concept, which is innovative in many ways. It should be noted that a number of significant strategic planning documents that determine a high status of culture as a national Russian priority appeared in 2008-2017. Thus, state cultural policy requires clear goals, principles and tasks, on the one hand, and the awareness of possible threats, on the other hand. The elements of scientific novelty are determined by the fact that the article justifies the necessity to understand the modern approaches towards the development and implementation of state cultural policy in the Russian Federation. At the same time, it is noted that the concept and strategy of cultural policy should take into account both the acknowledged political ideology and the issues of financial support of the cultural sphere.
\end{abstract}

Keywords: Culture, Cultural policy, Threats to cultural policy goals, the principle of culture financing.

\footnotetext{
${ }^{1}$ Kuban State Technological University (KubSTU) 2, Moskovskaya Street, Krasnodar, Russia, 350072. E-mail: milenae2007@yandex.ru

2 North Caucasus Federal University (NCFU) 1, Pushkina Street, Stavropol, Russia, 355009. E-mail: rusetskiym@yandex.ru

${ }^{3}$ Kuban State Technological University (KubSTU) 2, Moskovskaya Street, Krasnodar, Russia, 350072. E-mail: molchan.alexey@gmail.com

${ }^{4}$ Kuban State Technological University (KubSTU) 2, Moskovskaya Street, Krasnodar, Russia, 350072. E-mail: muhina2008@mail.ru

${ }^{5}$ Kuban State Technological University (KubSTU) 2, Moskovskaya Street, Krasnodar, Russia, 350072. E-mail: arozita@mail.ru
} 


\section{Introduction}

Culture and art in a civilized society are considered as the most important resources of socio-economic development contributing to the human capital formation. State cultural policy must be oriented towards national unity on the basis of common humanistic values to improve the living standards. According to "The Basics of State Cultural Policy", culture is a set of formal and informal institutions, phenomena and facts that affect the preservation, production, transmission and distribution of spiritual values. In the same document cultural policy is defined as actions perpetrated by "the government bodies of the Russian Federation and by social institutions aimed at the support, preservation and development of all cultural branches, all types of creative activities of Russian citizens and at the personality development on the basis of the value system inherent of Russian society" [12].

The state as the most important subject of cultural policy must form the social cultural life in general. At the same time, the state must solve two complex, often controversial tasks in the cultural sphere of society. First, the state must conduct its own cultural policy. Second, taking into account a wide range of subjects of state cultural policy and the variety of its objects, the state should effectively carry out the task of harmonizing the cultural needs and interests of all socially important groups and strata. The preamble to the report of the Ministry of Culture "Culture of Russia in 2012-2017. Facts and Figures" quotes the President of the Russian Federation, Vladimir Putin. "To preserve our identity is extremely important in the turbulent age of technological changes, it is impossible to overestimate the role of culture, which is our national civilizational code that unleashes human creative potential" [9]. This statement underscores the importance of constant research work for assessing the role and practice of the culture branch development in Russia, for shaping the organizational-economic and financial conditions for the development and implementation of Russian cultural policy.

The following aims were set in the course of the research:

- to systematize the goals in the cultural sphere of Russia taking into account a number of new strategic documents that regulate the main directions of state cultural policy at the modern stage of modernizing society;

- to comprehend the reality of the set tasks from the standpoint of possible state financing of the priority directions of cultural policy, the use of the market principles for searching additional sources of economic support of the culture branch;

- to set aims before the subjects of state cultural policy to take into account risk factors and threats, which may emerge in implementing both current and strategic goals.

\section{Methodology}

The subject of the research includes the directions and specifics of state cultural policy due to its importance for innovative social development under the conditions of modernizing Russian economy and with regard to its national security. The object of the research deals with the goals, problems and threats to the formation and implementation of cultural policy in the Russian Federation as well as with the search of possible solutions.

Ideological, cultural and socio-economic transformations of foreign scientists' views on the significance and priorities of general systematic image of a social state, the models and methods of forming national cultural policy are presented in the works of F. Matarasso, C. Landry, M. Pachter and A. Wiesand. The theoretical and practical aspects of implementing cultural policy in the Russian Federation, the problems of developing and improving its national model are presented in the works of O.N. Astafieva, L.E. Vostriakov, S.N. Gavrov 
and others. Some approaches to the problem of financial support of the culture branch are considered by L.E. Vostriakov, S.D. Valentei, L.N. Lykova, L.A. Efremova, G.I. Lazareva and others.

The information basis of the article included: normative legal acts that regulate the processes of methodological, organizational, financial support of state services in the culture branch; publications in periodical relevant journals; statistical data; Internet sources; the materials of the Ministry of Culture of the Russian Federation; other official sources of information. The validity of the results and recommendations is provided with the complex application of general scientific methods such as the dialectical means of cognitions, the system approach, the principles of formal logic and others.

\section{Results}

\subsection{The characteristics of goals and models of cultural policy}

In the international documents the sphere of the world cultural industry is characterized by intensive development, which provides a significant contribution to the gross national product. The cultural industry plays an important role in modern social development, in the generation of cultural heritage of each individual country. At the same time, a significant increase in the role of culture at the regional and local levels is highlighted, since it is at these levels where the tasks of forming human capital can be completely achieved. Its qualitative level should be characterized not only by professionalism but also by the presence of high spirituality and morality.

Similar tendencies can be seen in Russia in the past two decades, despite a number of problems and threats. They are manifested both in the course of implementing the priorities of national cultural policy, searching the formation and development models and in solving the problems of financial support of the culture branch. Presently, the development of cultural activities is accompanied by ideological, cultural and socioeconomic transformations of Russian society. The necessity to consider the given social changes, summing up and evaluating the results of the previously declared goals of cultural policy in the country, nominating and justifying its new priorities led to a number of important legal acts, concepts and strategies in the sphere of Russian culture. These documents emphasize that state cultural policy is to ensure priority cultural and humanitarian development as the basis for economic prosperity, state sovereignty and civilizational identity of the country $[12,15]$. The goals, principles and tasks of implementing state cultural policy are clearly presented in "The Fundamentals of State Cultural Policy" (hereinafter - FSCP) approved by the Decree of the President of the Russian Federation of December 24, 2014 № 808. At the same time, the goals of state cultural policy are regularly specified and supplemented. For instance, in "The National Security Strategy of the Russian Federation for the Period up to 2020" approved by the Decree of the President of the Russian Federation of May 12, 2009 №. 537 culture is considered as one of the strategic national priorities in the long term. "The Strategy of Economic Security of the Russian Federation for the Period up to 2030" approved by the Decree of the President of the Russian Federation of May 13, 2017 indicates "the prevention of a decline in the living standards" as one of its goals [13]. "The Concept of Longterm Socio-economic Development of the Russian Federation for the Period up to 2020" names "the increasing role of human capital as the main factor of economic development" as the third challenge [8].

The state and society are increasingly aware of the importance of culture and cultural policy in the life of the country, in the formation of a harmoniously developed personality and in the strengthening of civil unity. "The Strategy of State Cultural Policy of the Russian Federation for the Period up to 2030" approved by the decree of the Government of the Russian Federation of February 29, 2016 basing on the provisions of FSCP was developed in terms of "goal-setting according to the intersectoral principle" [15]. The use of the given approach allows considering state cultural policy from the standpoint of involving all spheres of state and public life and types of cultural activities. The intersectoral approach to the interpretation of the 
cultural policy essence makes it possible to expand its tasks by including such cultural policy objects as humanities, education, interethnic relations, the support of Russian culture abroad, international humanitarian and cultural cooperation as well as the citizens' upbringing and self-education, enlightenment, the development of the children's and youth movement, the formation of the country's information space.

As a result of the planned strategic changes the documents of the Ministry of Culture of the Russian Federation the year of 2016 is declared as the year of implementing state cultural policy "on the systematic intersectoral basis" [6]. Fulfilling goals and tasks set in "The Strategy of State Cultural Policy of the Russian Federation for the Period up to 2030" is provided by the action plan for 2016-2018. It is being implemented by the federal executive bodies, executive regional authorities, public and non-profit organizations.

Presently, there are quite a lot of typologies of policy models in the sphere of culture. The process of developing approaches to substantiating the role, goals and mechanisms for the development and implementation of cultural policy has evolved as follows. In the early 1970 s the so-called "new cultural policy" began to take shape to replace the doctrine of the "ennobling social role" of culture. It was based on the idea of democratization of culture (culture for everyone) in return for the policy of cultural democracy (culture for all). In the late 1980s and early 1990s the instrumental approach to cultural policy was formed, when "the fundamental value of culture was determined by its ability to serve various political goals and strategies aimed at social development or solving social problems" [14]. At that time politicians and artists began to show interest in "the prospects of investment in culture" [11]; the concepts of culture as a means of social development appeared. The researches of that time showed that "any cultural activity and, accordingly, any investment in culture have the inevitable socio-economic effect and are for the benefit of society in general" [11].

\subsection{The evaluation of threats to cultural policy in the Russian Federation}

Naturally, a number of questions arise. What principles should the concept and strategy of national cultural policy in Russia take into account? What model of its development can be selected? What experience of the developed countries can be used in Russia? A brief summary of a number of scientific works of foreign authors enabled to formulate some conclusions and generalizations.

The authors of the given article completely support the importance of the goals declared in the strategic documents about the role of culture in modernizing socio-economic development of modern society. These goals are evaluated by renowned Russian scientists in cultural studies and philosophy [1, 2, 4]. However, as we consider, the financial aspects of solving such significant tasks should be taken into account. In this regard, we briefly reviewed the risks and threats on the basis of the information presented in current documents reflecting the directions of reforming cultural policy in the Russian Federation (Table 1). At the same time, it should once again be noted that state cultural policy is acknowledged as "an integral part of national security strategy of the Russian Federation" [12].

Table 1. The main threats to national security of the Russian Federation connected with underestimating the role of culture $[5,6,12,15]$.

\begin{tabular}{|l|l}
$\begin{array}{l}\text { "The Strategy of State Cultural Policy of the Russian } \\
\text { Federation for the Period up to 2030" indicates the } \\
\text { following risks and threats: }\end{array}$ & $\begin{array}{l}\text { "The Fundamentals of State Cultural Policy" and } \\
\text { the state reports of the Ministry of Culture of the } \\
\text { Russian Federation in 2016-2018 indicate the } \\
\text { following risks and threats: }\end{array}$
\end{tabular}




\begin{tabular}{|c|c|}
\hline $\begin{array}{l}\text { 1. Impossibility to implement socio-economic } \\
\text { modernization without planned and regular } \\
\text { investments into people. }\end{array}$ & $\begin{array}{l}\text { 1. Impossibility of the country's to intensive } \\
\text { development, which could ensure the state's } \\
\text { preparedness to respond to the challenges of the } \\
\text { modern world without increasing investments in } \\
\text { human capital }\end{array}$ \\
\hline $\begin{array}{l}\text { 2. Reducing influence of Russian culture in the } \\
\text { world due to the decreased economic } \\
\text { opportunities to support it abroad. }\end{array}$ & $\begin{array}{l}\text { 2. A lack of investments into human capital can } \\
\text { lead to a further threat of a humanitarian crisis. }\end{array}$ \\
\hline $\begin{array}{l}\text { 3. Threat to national security and integrity of the } \\
\text { Russian Federation as a result of inadequate use } \\
\text { of its cultural potential as a factor of socio- } \\
\text { economic development. }\end{array}$ & $\begin{array}{l}\text { 3. The necessity to increase the status of state } \\
\text { cultural policy to the general national level in } \\
\text { order to overcome intersectoral and interregional } \\
\text { controversies in the issues of cultural } \\
\text { development. }\end{array}$ \\
\hline $\begin{array}{l}\text { 4. Risks of preserving the united cultural space as } \\
\text { a result of regional disproportions in access to } \\
\text { services, expenditures on culture and } \\
\text { infrastructure development. }\end{array}$ & $\begin{array}{l}\text { 4. Increasing threats to national security in the } \\
\text { sphere of culture due to the erosion of traditional } \\
\text { Russian spiritual and moral values and the } \\
\text { weakening unity of the multinational people of } \\
\text { the Russian Federation. }\end{array}$ \\
\hline $\begin{array}{l}\text { 5. Underestimation of cultural potential for } \\
\text { harmonizing social relations. Socially vulnerable } \\
\text { groups of the population, including disabled } \\
\text { people, require special measures of cultural } \\
\text { support. }\end{array}$ & $\begin{array}{l}\text { 5. The prevalence of direct budget financing in the } \\
\text { Russian culture funding system and an almost } \\
\text { complete lack of other sources of funding } \\
\text { available for foreign cultural institutions. }\end{array}$ \\
\hline $\begin{array}{l}\text { 6. Insufficient activity and weak involvement of } \\
\text { public institutions into implementing cultural } \\
\text { policy, despite annually increasing grants for } \\
\text { creative projects and for implementing civil } \\
\text { initiatives. }\end{array}$ & $\begin{array}{l}\text { 6. A systematic reduction in expenditures on } \\
\text { culture in the consolidated budget and in relation } \\
\text { to the gross domestic product of the Russian } \\
\text { Federation. }\end{array}$ \\
\hline $\begin{array}{l}\text { 7. The existing volumes of extra-budgetary funds } \\
\text { in the sphere of culture do not contribute to the } \\
\text { growth of implementing public initiatives without } \\
\text { budgetary financing. }\end{array}$ & $\begin{array}{l}\text { 7. A low level of budgetary support of culture on } \\
\text { the basis of the expenditure indicators calculated } \\
\text { per capita in comparison with the countries of the } \\
\text { Organization for Economic Co-operation and } \\
\text { Development. }\end{array}$ \\
\hline $\begin{array}{l}\text { 8. A decreasing share of expenditures on culture } \\
\text { in the expenditures structure of households. }\end{array}$ & $\begin{array}{l}\text { 8. The objective possibility for decreasing extra- } \\
\text { budgetary revenues of culture institutions due to }\end{array}$ \\
\hline
\end{tabular}




\begin{tabular}{|l|l|}
\hline $\begin{array}{l}\text { 9. A specific problem of forming cultural policy of } \\
\text { "free-riding" attitudes in some RF subjects in } \\
\text { relation to the state obligations. }\end{array}$ & $\begin{array}{l}\text { their limited seating capacity and also due to } \\
\text { increasing prices leading to the reduced availability } \\
\text { of cultural values for the general public. }\end{array}$ \\
\hline $\begin{array}{l}\text { 10. A "shallow" bureaucratic approach to culture } \\
\text { as well as an understanding of culture as a service } \\
\text { area and not as a public good generates a low } \\
\text { social status of culture that does not correspond } \\
\text { to the strategic interests of the Russian }\end{array}$ & $\begin{array}{l}\text { 9. An almost complete lack of ready-to-use } \\
\text { methods and tools that would enable to make use } \\
\text { of modern experience of forming a multi-channel } \\
\text { system of culture funding that, in turn, would be } \\
\text { able to attract significant extra-budgetary } \\
\text { investments and to provide the sustained } \\
\text { development of culture. }\end{array}$ \\
\hline
\end{tabular}

The data presented enable to conclude that the structural transformations that occurred in Russia in the sphere of culture management and the reforms of the budgetary system lead to the increased relevance of similar researches. There are some other approaches to the models of cultural policy in the modern world, which offer public support or independent survival as the main criteria.

\section{Discussion}

"The study of the main stages in the formation and development of the concept of state cultural policy in Russia within the period analyzed in the article clearly demonstrates its interconnection with the main directions of budgetary policy" [10]. Table 2 presents the indicators characterizing the process of culture funding by means of expenditures of the consolidated budget of the Russian Federation. The data, as we believe, are necessary for evaluating the financial opportunities for supporting the main cultural policy directions through budgetary funds.

Table 2. The indicators of budgetary funding of culture and cinematography in the Russian Federation in 2014-2017 [3, 5, 6].

\begin{tabular}{|l|c|c|c|c|c|c|}
\hline \multicolumn{1}{|c|}{ The indicator } & 2014 & 2015 & 2016 & 2017 & \multicolumn{2}{c|}{$\begin{array}{c}\text { Change from 2014 } \\
\text { to 2017 }\end{array}$} \\
\cline { 4 - 7 } & & & & & 20 absolute & $\%$ \\
\hline $\begin{array}{l}\text { Expenditures of the consolidated budget } \\
\text { and the budgets of state extra-budgetary } \\
\text { funds on culture and cinematography } \\
\text { (billion RUB) }\end{array}$ & 410.0 & 396.5 & 422.8 & 492.9 & +82.9 & +20.2 \\
\hline $\begin{array}{l}\text { The share of expenditures on culture and } \\
\text { cinematography in total expenditures (\%) }\end{array}$ & 1.5 & 1.3 & 1.5 & 1.5 & 0 & - \\
\hline $\begin{array}{l}\text { Expenditures on culture and } \\
\text { cinematography (\% of GDP) }\end{array}$ & 0.57 & 0.54 & 0.49 & 0.54 & -0.03 & -5.3 \\
\hline
\end{tabular}


According to the data presented in Table 2 concerning the volumes of budgetary funding of culture and cinematography, their share in total expenditures of the consolidated budget and the budgets of state extra-budgetary funds, no positive tendencies were discovered. The dynamics of the share of expenditures on culture and cinematography taken as a percentage of GDP are not encouraging either. As a result, we can make a conclusion about the crisis of the paternalistic model of cultural policy and the need to move to the partnership model. This fact has been widely discussed in the scientific circles Western countries and Russia for a long time. In Russia, however, "there was also a partial transition to the partnership model of cultural policy ... for the first time in the country's history, culture was considered not only as a costly sphere" [2]. Insignificant volumes of state financing of the culture sphere put forward the task of "learning how to earn money in order to partially cover expenses" [2].

If we assess the culture financing situation in Russia in terms of international comparisons, our country occupies a very modest position in the list of OECD countries with cultural sector financing amounting to 6.5-7.0 billion USD. In Germany the amount of state funding of culture is about 14 billion USD. In the United Kingdom it is about 9 billion USD. "In terms of per capita expenditures on culture, Russia is at the bottom of the list of 25 OECD countries outpacing only Greece, Bulgaria and Cyprus" [5, 6].

Among the main cultural priorities of the new century the state task not to exclude responsibility for the development of culture is fairly declared. The state is the main guarantor of the realization of the citizens' constitutional rights to participate in cultural life and to use cultural institutions, to equal access to cultural values, to information resources and to create basic conditions for access to cultural goods. The movement towards a market economy raises the question of adjusting the state's impact on the spheres related to the formation of human potential, including the culture sphere.

The head of the Cultural Policy Research Institute (Bonn) A. Wiesand suggests "the principle of financing the culture sphere but not political grounds" as the basic criterion for classifying the current models of cultural policy [16]. At the same time, two main models of the development of cultural policy are singled out, one of which is based on the traditional idea of public support for art and culture, and the second one is based on the market model. A. Wiesand predicts the following situation, assessing the role of the state in financing the culture sphere as a market economy develops, "The state should become a source of innovation and provide culture with flexible financing with the use of various funds; whereas the population should have access to cultural services oriented to a specific customer" [16]. However, whatever model is chosen as the base for a particular country, it should be noted that these are often only formally proclaimed principles, which are in reality greatly corrected by informal rules, taking into account the peculiarities of its ideological, moral, political and socio-economic development. Some countries fluctuate between new trends and traditional ideas. However, in our opinion consistent with the opinion of many scientists, the state will remain the main subject of state cultural policy for a long time. It can be explained by the fact that the state forms a significant amount of financial resources keeping them in its disposal, determines the priorities of national cultural policy and coordinates the interests of various segments of the country's population. The state also possesses a variety of management bodies, the main purpose of which is a targeted and effective impact on various sectors of the culture sphere.

\section{Conclusion}

In the article an attempt is made to consider the specifics of Russian reality in the formation of the basics of a new model of state cultural policy at the turn of the XX-XXI centuries. Russia, as many other countries is in search of options for developing a model of cultural policy that could combine the principles of the paternalistic and partnership models. During the development of the national concept of cultural policy in Russia, the experience of foreign countries is studied; in these countries the demand for the market model 
of formation and financing is rather high. "Many people believe that now there is "a turn to culture", since culture comes to the foreground and even economy and politics experience its multiple influences" [14].

Presently, the ambivalent attitude toward determining the role of cultural policy for society can be noted in Russia. Evidently, the market model of the cultural policy concept demonstrates a sufficient level of efficiency in countries that have begun implementing its principles. On the other hand, in Russia taking into account the large number of poorly provided population, there is a need to maintain a large sector of cultural services financed from budget funds. At the same time, the creation and development of new models of cultural policy should be based on the gained experience and should reflect international trends. Such approaches to the formation of models of cultural policy are called "integrative methodology".

The authors of the given article hold the opinion that such an approach should be considered as the main basis for developing a national model of cultural policy in Russia. At the same time, attention should be drawn to the fact that national concepts of cultural policy are not static and set once and for all. On the contrary, the foreign and domestic practice proves the constantly changing nature of cultural policy. It is connected with constantly changing economic, political and cultural priorities of each country and with available funding sources.

The following conclusions can be drawn basing on the researches conducted by the authors of the given article.

1) The increasing rate of economic development, economic structural changes caused by the transition to the innovative type of development result in the increasing role of human capital in the socio-economic process. The leading role in the formation of human capital creating the economy of knowledge is given to the culture sphere.

2) Basing on "the study of the functions of government bodies and economic entities in the culture sphere of the Russian Federation, it should be concluded that determining priorities in the culture sphere is a statepublic principle" [7].

3) "As the data of implementing the Federal Targeted Program "Russian Culture" (2012-2018)" the state failed to create conditions for attracting extra-budgetary funds to finance the culture sphere. During the implementation period 20.5 billion RUB is annually provided from the budget and the amount of attracted funds from other sources is only 486 million RUB" [10].

4) Taking into account the practice of financing the branches of the culture sphere and as the material of this article shows, budgetary allocations from the federal budget are clearly not enough for these purposes. "Under these conditions, the model of performance-oriented budgeting can and must be modified into a model of functionally-oriented financing of culture" [7]. This approach, in our opinion, still remains in demand and requires further research.

The reviewed main strategic documents on the cultural, socio-economic politics and on the strategy of economic security of Russia enable to note the following:

- in "The Fundamentals of State Cultural Policy" culture was elevated to national priorities rank; it is acknowledged as the most significant factor of improving the living standards and harmonizing social relations, as s guarantor of preserving the united cultural space and territorial integrity of the Russian Federation;

- the state is the main strategic investor in culture and culture institutions of the Russian Federation, which makes it a key subject of cultural policy;

- the strategy of cultural policy formulates the priority directions for minimizing current risks in the culture sphere; 
- spiritual-moral values are for the first time identified as one of the main bases of national security;

- the implementation of the innovative way of economic development will lead to increasing budgetary expenditures on culture and cinematography from $0.7 \%$ to $1.5 \%$ of the gross domestic product in 2017 2020 [8].

It should be specifically noted that the Strategy of State Cultural Policy of the Russian Federation and other documents of the Government of the Russian Federation and the Ministry of Culture not only set the task "to increase the financing of culture from all sources to $1.4 \%$ of gross domestic product by 2030" [15] but also indicate possible ways of its performing. Taking into account international experience, such sources of growth in the share of extra-budgetary funds should include the standards for budget financing; a national lottery in the culture sphere; an effective system of tax preferences; an institute of budget assignments; marked taxes; funds of target capital (endowment funds) by types of cultural activities, etc.

Therefore, performing the perspective tasks of cultural policy in the Russian Federation up to 2030 requires further research both from the standpoint of solving cultural policy tasks and in terms of the role of culture in providing the sustained economic growth of the country and in supporting its national security.

\section{Conflict of interest}

The authors confirm that the data do not contain any conflict of interest.

\section{Footnotes}

1. Astafyeva, O.N. (2013). Cultural policy: theoretical aspects and implementation practice. Modern Science. Actual Problems of Theory and Practice. Series "Humanities", №1-2, pp. 22-29.

2. Vostriakov, L.E. (2011). State cultural policy: from a paternalistic model to a partnership model? Administrative Consulting, №4, pp. 140-155.

3. Valentei, S.D., \& Lykova, L.N. (2017). The analysis of tendencies in the budgetary-taxation sphere of Russia. Plekhanov Russian University of Economics Bulletin, Iss.10. Available at: https://www.rea.ru/ru/news/SiteAssets/bulleten-10.pdf. (Accessed 14.07.2018).

4. Gavrov, S.N. (2013). Cultural policy: public-state interaction, technological effectiveness, versatility. Modern Science. Actual Problems of Theory and Practice. Series "Humanities", №1-2, pp. 63-65.

5. The state report on culture in the Russian Federation in 2015. Available at: http://doklad-ros-kultura2015.doc. (Accessed 04.07.2018).

6. The state report on culture in the Russian Federation in 2016. Available at: http://www.mkrf.ru/activities/reports/report2016 / Gosudarstvennyj-doklad-o-sostojanii-kultury-vRossijskoj-Federacii-v-2016-godu.pdf. (Accessed 04.07.2018).

7. Efremova, L.A. (2009). Function-oriented financing of culture (Cand. of Economics thesis). SaintPetersburg State University of Economics and Finances, $177 \mathrm{p}$.

8. The Concept of Long-term Socio-economic Development of the Russian Federation for the Period up to 2020. Available at: http://74330s020.edusite.ru/DswMedia/koncepciyadolgosrochnogosocial-

-no-yekonomicheskogorazvitiyarossiyskoyfederaciinaperioddo2020goda.pdf. (Accessed 02.07.2018).

9. Culture of Russia in 2012-2017. Facts and Figures. Available at: http://www.mkrf.ru/activities/reports/ (Accessed 06.07.2018). 
10. Lazareva, G.I., Efremova, L.A., Rusetskaya, E.A., Ulibina, L.K., \& Okorokova, O.A. (2018). The Role of Culture in the Development of Society and the Opportunities to Finance It in Russia. Journal of History Culture and Art Research, 7(2), 72-86. DOI: http://dx.doi.org/10.7596/taksad.v7i2.1583

11. Matarasso, F., Landry, C. (2002). Balancing act: twenty-one strategic dilemmas in cultural policy. Cultural Policy in Europe: Choice of Strategy and Benchmarks. Moscow: Publishing House "Libereya", p. 128.

12. The Fundamentals of State Cultural Policy № 808 of December 24, 2014. Available at: http://legalacts.ru/doc/ukaz-prezidenta-rf-ot-24122014-n-808/ (Accessed 10.07.2018).

13. The Strategy of Economic Security of the Russian Federation for the Period up to 2030" of May 13, 2017. Available at: http://economy.gov.ru/minec/press/news/2017150502. (Accessed 12.07.2018).

14. Pachter, M., Landry, C. (2003). Culture at the crossroads: culture and cultural institutions at the beginning of the 21st Century. Moscow: Classics-XXI, $96 \mathrm{p}$.

15. The Strategy of State Cultural Policy of the Russian Federation for the Period up to 2030 №326-r of February 29, 2016. Available at: http://www.garant.ru/ products/ipo/prime/doc/71243400/ (Accessed 14.07.2018).

16. Fisher, R., \& Mitchel, R. (1992). Professional Managers for the Arts and Culture? Training of cultural administrators and the art managers in Europe. (Helsinki: CIRCLE Report, Art Council of Finland, 1992), pp. $36-38$

\section{References}

Astafyeva, O. N. (2013). Cultural policy: theoretical aspects and implementation practice. Modern Science. Actual Problems of Theory and Practice. Series "Humanities", №1-2, pp. 22-29.

Culture of Russia in 2012-2017. Facts and Figures. Available at: http://www.mkrf.ru/activities/reports/ (Accessed 06.07.2018).

Efremova, L. A. (2009). Function-oriented financing of culture (Cand. of Economics thesis). Saint-Petersburg State University of Economics and Finances, 177 p.

Fisher, R. \& Mitchel, R. (1992). Professional Managers for the Arts and Culture? Training of cultural administrators and the art managers in Europe. (Helsinki: CIRCLE Report, Art Council of Finland, 1992), pp. 36-38.

Gavrov, S. N. (2013). Cultural policy: public-state interaction, technological effectiveness, versatility. Modern Science. Actual Problems of Theory and Practice. Series "Humanities", №1-2, pp. 63-65.

Lazareva, G. I.; Efremova, L. A.; Rusetskaya, E. A.; Ulibina, L. K. \& Okorokova, O. A. (2018). The Role of Culture in the Development of Society and the Opportunities to Finance It in Russia. Journal of History Culture and Art Research, 7(2), 72-86. DOI: http://dx.doi.org/10.7596/taksad.v7i2.1583

Matarasso, F. \& Landry, C. (2002). Balancing act: twenty-one strategic dilemmas in cultural policy. Cultural Policy in Europe: Choice of Strategy and Benchmarks. Moscow: Publishing House "Libereya", p. 128.

-no-yekonomicheskogorazvitiyarossiyskoyfederaciinaperioddo2020goda.pdf (Accessed 02.07.2018). 
Pachter, M. \& Landry, C. (2003). Culture at the crossroads: culture and cultural institutions at the beginning of the 21st Century. Moscow: Classics-XXI, $96 \mathrm{p}$.

The Concept of Long-term Socio-economic Development of the Russian Federation for the Period up to 2020. Available at: http://74330s020.edusite.ru/DswMedia/koncepciyadolgosrochnogosocial-

The Fundamentals of State Cultural Policy № 808 of December 24, 2014. Available at: http://legalacts.ru/doc/ukaz-prezidenta-rf-ot-24122014-n-808/ (Accessed 10.07.2018).

The state report on culture in the Russian Federation in 2015. Available at: http://doklad-ros-kultura2015.doc. (Accessed 04.07.2018).

The state report on culture in the Russian Federation in 2016. Available at: http://www.mkrf.ru/activities/reports/report2016 / Gosudarstvennyj-doklad-o-sostojanii-kultury-vRossijskoj-Federacii-v-2016-godu.pdf (Accessed 04.07.2018).

The Strategy of Economic Security of the Russian Federation for the Period up to 2030" of May 13, 2017. Available at: http://economy.gov.ru/minec/press/news/2017150502 (Accessed 12.07.2018).

The Strategy of State Cultural Policy of the Russian Federation for the Period up to 2030 №326-r of February 29, 2016. Available at: http://www.garant.ru/ products/ipo/prime/doc/71243400/ (Accessed 14.07.2018).

Valentei, S. D. \& Lykova, L. N. (2017). The analysis of tendencies in the budgetary-taxation sphere of Russia. Plekhanov Russian University of Economics Bulletin, Iss.10. Available at: https://www.rea.ru/ru/news/SiteAssets/bulleten-10.pdf (Accessed 14.07.2018).

Vostriakov, L. E. (2011). State cultural policy: from a paternalistic model to a partnership model? Administrative Consulting, №4, pp. 140-155. 